\title{
THE REVIEW OF PLANNING PRACTICE IN BROWNFIELD REGENERATION - SOME EUROPEAN EXPERIENCES
}

\author{
Ana Perić* \\ University of Belgrade, Faculty of Architecture, Belgrade, Serbia
}

The research subject is the analysis of the possible ways to achieve stakeholder compliance in the brownfield regeneration process. In a narrow sense, the treatment of brownfield sites within different planning systems is considered. Each of the selected planning systems is described through the institutional structure as well as the regulative framework. The aim of the paper is to show urban planning mechanisms that are used for the establishment of collaboration between different stakeholders involved in brownfield regeneration. In the very beginning, a brief history of spatial development is given. A special emphasis is on the current trends in the brownfield regeneration. The central part of the paper deals with the overview of selected examples in terms of brownfield regeneration. It is followed by the overview of the institutional aspect within the planning system in Switzerland and Austria. The determination of the responsible institutions for the brownfield regeneration process is of particular importance. Also, it is important to show the basic documents dealing with the above-mentioned topics. However, the focus of research concerns the collaborative procedures to achieve the successful regeneration of brownfields. Those results stem from the analysis of the brownfield sites examples. Namely, the first example relates to the regeneration of wood-industry complex in the Swiss town of Solothurn, while the second case indicates the regeneration of cable and wire factory in Vienna. The final section of the paper systemizes the experiences from the developed countries which provide a possible formulation of general brownfield regeneration model to be applied within different contexts.

Key words: Brownfield regeneration, Collaboration, Stakeholders, Interest compliance, Switzerland, Austria

\section{INTRODUCTION}

Brownfield redevelopment is defined as a redevelopment of "any land or premises which has previously been used or developed and is not currently fully in use, although it may be partially occupied or utilized, (...) and which may also be vacant, derelict or contaminated" [01]. It has opposite goals from those which are the expression of modern urban growth trends. Also, it occurs under the direct impact of socio-economic factors, as an expression of a broader socio-political context. Only the synthesis of these factors can lead to a common goal - the transformation of space.

Since the 1980s brownfield regeneration has become a central topic in most important international documents $[12,02,15]$. This especially relates to urban practice in North America (U.S. and Canada) as well as Western Europe. However, the new millennium trend of sustainable regeneration has also spread to the transition countries. Nevertheless, the mentioned countries tend to integrate European models of urban transformation. Since they established market economies, these countries have become open to global influences and foreign direct investment. According to the views of certain authors, cities have fallen under the simultaneous influence of the local system of social transformation as well as global processes, which created a specific 'postsocialist' context of urban restructuring [15]. This is particularly done by the creation and adoption of many local planning documents, which were prepared on the base of western experience.

The issue of the collaboration among various actors in the brownfield regeneration process is considered to be complex, because it is often very difficult to examine and define the interests of different stakeholders. This problem is present even in the developed countries as evidenced by the studies where brownfield regeneration is seen as a specific urban process due to a large number of participants $[03,04,08]$. According the same source, communication, understand 
ing and trust among stakeholders are the key goals in brownfield regeneration process. Research also shows that the understanding of the process with a large number of participants led by different driving forces can be interpreted by the network as a basic concept, where the network is considered as a set of relations between different groups composed of actors with same interest [05]. This can be explored on the brownfield regeneration example, which begins as a specific process, but it has the potential to spread through a process of imitation, learning, adaptation, evolution, and fading of actors and networks that were originally involved in the process.

The main hypothesis of the research is that brownfield regeneration process should be placed within the collaborative planning paradigm, i.e. within the context of multiple stakehold- ers and their often contradictory interests, where the final aim of such collaboration is a consensus building and solution achievement. The aim of the research is to assess to what extent the brownfield regeneration process has been really collaborative within the selected cases.

\section{REGULATIVE FRAMEWORK OF BROWNFIELD REGENERATION}

Since one of the main aims of the Swiss spatial planning policy is economical use of the limited land area [17], the regeneration of the brownfield sites is one of the top mechanisms to sustainable spatial development. In order to achieve optimum spatial organisation, the coordination of all the activities with spatial impact is needed. This relates to the representatives of the federal, cantonal, and communal authorities [09]. The detailed institutional framework is shown in the Table 1.

Table 1: The main institutional and legislative framework for brownfield regeneration in Switzerland

\begin{tabular}{|c|c|c|c|}
\hline Functional level & Administrative organization & Institutional framework & Planning instruments \\
\hline \multirow{3}{*}{ National } & \multirow{3}{*}{ Confederation } & Federal Council & $\begin{array}{l}\text { Federal Law on Spatial } \\
\text { Planning }\end{array}$ \\
\hline & & $\begin{array}{l}\text { Federal office for } \\
\text { Spatial Development }\end{array}$ & $\begin{array}{l}\text { Swiss Planning Policy } \\
\text { Guidelines }\end{array}$ \\
\hline & & Other federal offices & $\begin{array}{l}\text { Sectoral strategies } \\
\text { Sectoral plans }\end{array}$ \\
\hline \multirow{3}{*}{ Cantonal } & \multirow{2}{*}{ Canton } & Cantonal governments & $\begin{array}{l}\text { Cantonal Planning and } \\
\text { Building Laws } \\
\text { Cantonal structure plan }\end{array}$ \\
\hline & & $\begin{array}{l}\text { Cantonal spatial } \\
\text { planning offices }\end{array}$ & Planning studies \\
\hline & Region & $\begin{array}{l}\text { Regional planning } \\
\text { associations }\end{array}$ & Regional structure plan \\
\hline Local & Commune & Communal authorities & $\begin{array}{l}\text { Communal Zoning and } \\
\text { Building regulations } \\
\text { Communal structure } \\
\text { plan } \\
\text { Land use plan } \\
\text { (M1:10.000) } \\
\text { Special plan } \\
\text { (M1:5.000) } \\
\text { Building regulations }\end{array}$ \\
\hline
\end{tabular}

(Source: Prepared by author according to Muggli, 2008)

Although the new article on spatial planning, incorporated in the Federal Constitution, transferred the responsibility for framework legislation on spatial planning to the confederation, the practice of planning implementation remained a matter of the cantons [13]. The transdisciplinary approach can be observed just in the process of collaboration between the confederation and cantons, which is the central postulate of cooperative federalism. This is achieved by the set of documents indicated in the table above, where the most important one is the Cantonal structure plan which should be approved by the federation as a proof of mutual collaboration. Also, the 
cantonal executives approve the communal zoning plans and building regulations. All communal zoning and building regulations are subject to a public referendum on local level [09]. The multidisciplinary approach is obvious on the federal level, where the other federal offices together with the Federal Office for Spatial Development participate in the spatial strategies and sectoral plans formulation. Also, many cantons provide the cantonal land use plans for the projects which are of special importance to their spatial planning policy, such as industrial zones or waste disposal sites of regional importance. In these cases, cantonal land use planning replaces communal land use planning confined to specific designated areas [13]. Stakeholder participation is seen is the fact that planning authorities have to inform the population about the structure plans and the land use plans. Everybody can object to these plans.
The responsible authorities have to consider the objections made and either accept them or give a reason for not accepting them [09]. According to the same source, the conflicts between communal and cantonal planning authorities are decided by the cantonal executive or finally, by the Federal Court of Law. Conflicts between cantonal and federal planning authorities are dealt with in a conciliation procedure [09].

In Austria, the crucial role in increasing awareness about brownfield regeneration lies in the hands of policy makers and the authorities. The main obstacle in efficient problem-solving at local level is the fuzziness of local authority competences in regard with the mentioned problem [06]. Some of the main institutions as well as their documents concerning brownfield regeneration on the national, state, and local level are given in the Table 2 below.

Table 2: The main institutional and legislative framework for brownfield regeneration in Austria

\begin{tabular}{|c|c|c|c|}
\hline Functional level & $\begin{array}{l}\text { Administrative orga- } \\
\text { nization }\end{array}$ & $\begin{array}{l}\text { Institutional } \\
\text { framework }\end{array}$ & Planning instruments \\
\hline \multirow{4}{*}{ National } & \multirow{4}{*}{ Federal Republic } & $\begin{array}{l}\text { Federal } \\
\text { administration }\end{array}$ & no federal competence in spatial planning \\
\hline & & $\begin{array}{l}\text { ÖROK - Austrian } \\
\text { Conference on } \\
\text { Spatial Planning }\end{array}$ & $\begin{array}{l}\text { ÖREK - Austrian spatial development concept } \\
\text { STRAT.AT - Spatial development strategy } \\
\text { Spatial Development Scenarios - Austria } 2030 \\
\text { Sectoral plans from different ministries }\end{array}$ \\
\hline & & $\begin{array}{l}\text { Austrian } \\
\text { Environment } \\
\text { Agency }\end{array}$ & National Policy Target \\
\hline & & $\begin{array}{l}\text { Ministry of } \\
\text { Environment }\end{array}$ & Enough Ground \\
\hline \multirow[b]{2}{*}{ Regional } & State (NUTS II) & $\begin{array}{l}\text { Länder } \\
\text { administration }\end{array}$ & $\begin{array}{l}\text { Spatial Planning Law (9 laws) } \\
\text { State Spatial planning concept }\end{array}$ \\
\hline & Region (<NUTS III) & $\begin{array}{l}\text { Regional } \\
\text { associations }\end{array}$ & $\begin{array}{l}\text { Regional spatial development concept } \\
\text { Regional spatial development programme } \\
\text { Sectoral spatial development programme }\end{array}$ \\
\hline Local & Municipality & $\begin{array}{l}\text { Municipal } \\
\text { administration }\end{array}$ & $\begin{array}{l}\text { Local spatial development programme } \\
\text { Local development scheme (M1:10.000) } \\
\text { Land use plan/ zoning plan (M1:5.000) } \\
\text { Lay out plan, local development plan } \\
(\mathrm{M} 1: 2.000,1: 1.000)\end{array}$ \\
\hline
\end{tabular}

The general conclusion about the Austrian institutional framework of brownfield regeneration can be drawn here. Firstly, of utmost importance are the two federal documents directly concerning the issue of brownfield regeneration, as well as the provincial instruments of implementation the brownfield policies. Secondly, the multidis- ciplinary approach is expressed in the activities of the Austrian Conference on Spatial Planning - ÖROK (Österreichische Raumordnungskonferenz). Its main role is to serve as a base for the informal cooperation between institutions responsible for spatial planning [11]. In a narrow sense, this means that all the sectoral policies 
the brownfield regeneration are integrated into the consistent policy of the one federal authority. It is not the case on the state level - there is a need for better exchange of experiences. This is also requested on local level, where the differences between municipalities come to the fore. Thirdly, transdisciplinary approach is noticed in the transfer of knowledge between the federal and lower levels of institutional structure, but also and vice versa. The top-down approach is not an obligation for brownfield regeneration in Austria, which has to be recognized as a great advantage of the entire system [14]. Finally, the involvement of stakeholders from diverse sectors is particularly simple on local level due to the territory coverage. Most municipalities mainly collaborate with private sector or the international organizations as partners in funding the brownfield regeneration projects.

\section{COLLABORATIVE PROCEDURES FOR SUCCESSFUL BROWNFIELD REGENERATION}

The collaborative procedures for successful brownfield regeneration are going to be presented and examined on the two selected case studies. The methodology used for the determination of the collaboration extent within the cases is based on the extensive semi-structured interviews conducted among the selected actors who were directly in charge of the preparation (planning) phase of brownfield regeneration process $[10,07,16]$. The structure of the interview as well as the section of the article that follows consists of several parts:

- Major stakeholders who have contributed to the project initiation;

- Planning experts in this project - their actions, organization and project management;

- Negotiation process and decision-making procedures in the specific project;

- Identifying the ways to conflict resolution.

\section{THE SWISS CASE - WOOD-INDUSTRY COMPLEX, SOLOTHURN}

The first case refers to the ex-wood-industry complex in Solothurn, the city in the central part of Switzerland. The site is located near the river Aare and occupies the territory of 107 hectares, what makes it the second largest brownfield area in Switzerland. During the past decades it was owned by the Norwegian company named Borregaard AG, which during the recent years, to be more precise in 2008 , lost the interest to continue with production due to a low profit.

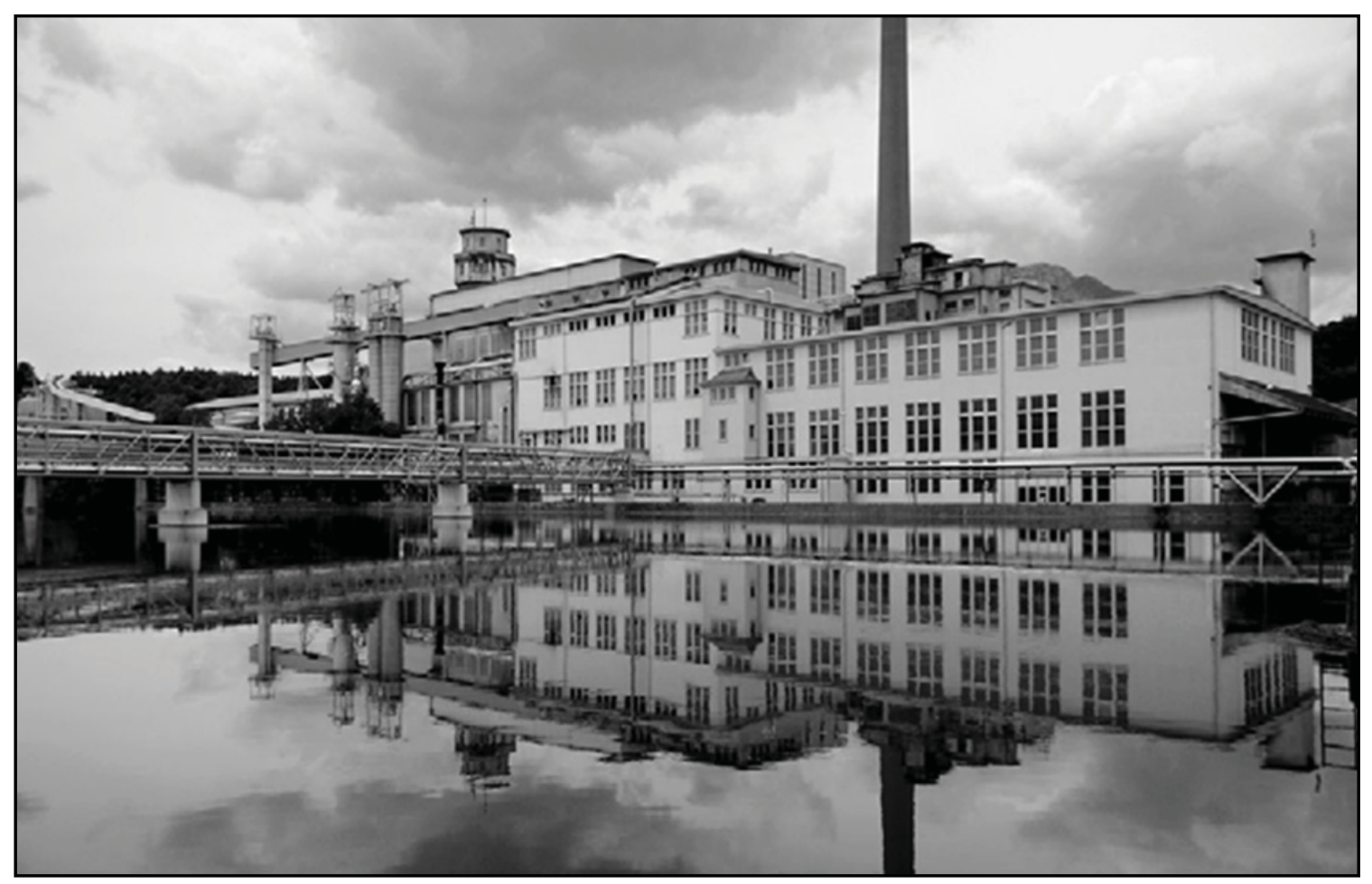

Figure 1: Ex-wood-industry complex in Solothurn, Switzerland 
1. The first idea about the possible start of brownfield regeneration process occurs due to a closure of the company Borregaard. Since it was an industry of the great importance for the whole region, in the very beginning many possible stakeholders were willing to participate. This, primarily, refers to the canton and municipality authorities as well as the private company representatives. In a meantime, the private companies appraised that any kind of investment will not be profitable, so the canton authorities separated from other stakeholders and took over the crucial role in the future process of brownfield regeneration. The major cantonal representative decided to start the liaison with the academic institutions in order to create the purposeful spatial intervention, so the head of the spatial planning institute from ETH Zurich was invited to participate in the process. All significant information in the process was transmitted in a direct way through the network building. The responsibility for the project group establishment, its members, and the leadership was in the hands of the cantonal authorities who, after the consultation with many partners, suggested the final organisational group. No external consultants were involved in the process, because of the canton's willingness to exert the direct influence. Therefore, the project management and all the responsibilities lay within the canton.

2. The participants in the process were numerous. Among the members of the cantonal offices we should mention the Department for Spatial Planning, Department for Economic Development and Labour, and Building Department. Besides the cantonal offices, local communities and landowners were also invited to express their own interests. The role of a technical expert in the whole process was dedicated to a broad-based technical evaluation committee, consisted of transportation/ infrastructure, urban and spatial planning, and economic experts. In this way, the project covered all the relevant interests. Despite the large number of participants, the whole process ran smoothly due to its efficient organisational structure. Namely, the whole organisation scheme was divided in two levels. On the strategic level, the main role of decision-making was assigned to the executive board, while on the operational level the most important body was the technical evaluation committee composed of the members with practical spatial planning expertise, i.e. planning teams whose main task was to create the urban design for the given area. To be more precise, the work of all the stakeholders was brought together by the chairman of the technical evaluation committee. He had the important control function - before, during, and after the interim meetings in plenary. Organisational level also comprises the organisation office which acted as a hub and to which the production of the protocols and reports was entrusted.

3. The negotiation and decision-making process took place within a structured procedure. The four invited teams presented their ideas at two meetings. The results of the consultations were communicated to the team. After the final presentations by the teams, the technical evaluation committee met for a two-day closed session to discuss the results and evaluate on the basis of a planning programme (with the required criteria). After extensive discussions, the technical evaluation committee formulated the recommendations to the executive board. Although the chairman of the committee had a great knowledge and negotiation skills, the recommendations were based on the stance of the whole team. The "external" negotiation, i.e. the negotiation with land owners, local municipality, and the canton of Solothurn, was conducted in the early phase of the process. At this stage, the investors were not included. The possible role of investor took over a real estate expert, who was also involved in the process.

4. The planning phase was relatively harmonious. All communication was placed via the representative of the canton, in consultation with the chairman of the technical evaluation committee. The conflicts have been managed in this group. The public had the opportunity to give comments on the results of the planning phase. They were informed on the progress made in the plan at regular intervals. However, there were no suggestions from the public in the mentioned phase. The specific way of planning phase organisation provided security to the potential investors. Also, the community could support the various participants, if there are different interests, for example between the land owners 
and investors through the presentation of their calls (e.g. round table). Nevertheless, the responsibility clearly lies within the canton.

\section{THE AUSTRIAN CASE - CABLE AND WIRE FACTORY, VIENNA}

The second example is the ex-cable and wire factory in Vienna, located in the municipal dis- trict of Meidling on the area of almost 7 hectares. For the entire century, the factory has been a prosperous enterprise with the several hundred employees. After the year 1989, due to a course of privatization, the company was sold and consequently started to weaken. Finally, in 1997 the plant was closed.

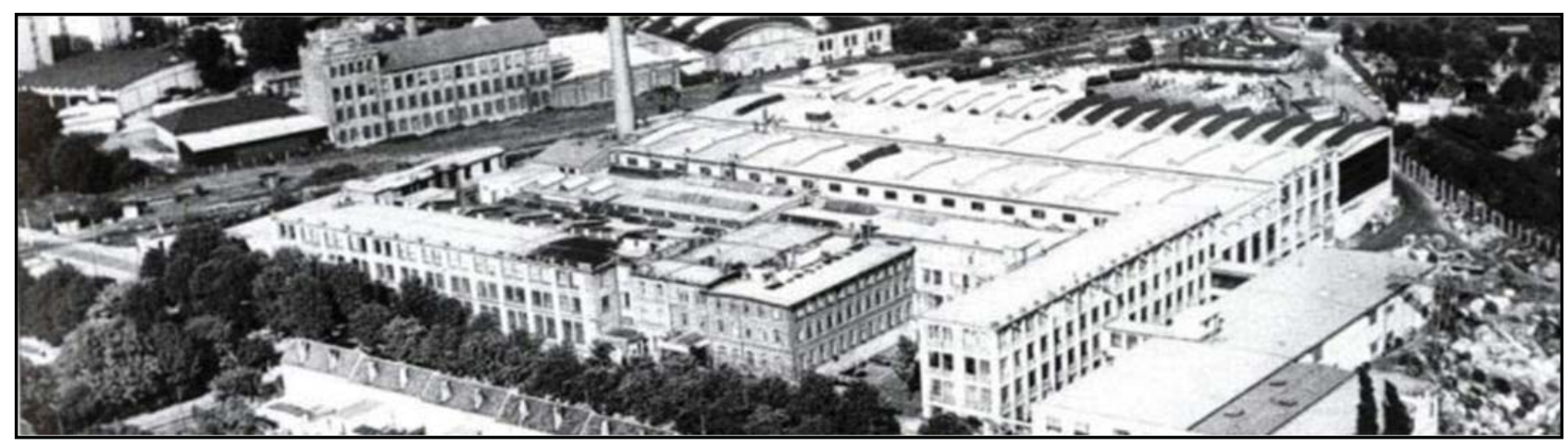

Figure 2: Ex-cable and wire factory in Vienna, Austria

1.Since the factory had the specific influence on the whole district, not only in terms of previous employees, but also the very special reference factor for the population, the first initiators of the possible area development were the laid-off staff and local residents. The citizens' participation was reflected in the organisation of a citizens' competition, where they were invited to provide any kind of suggestions for future development. The jury, which was intentionally not formed of a majority of urban planners, but from the chairman of the district office, local parish priest, journalist, and the representatives of the City of Vienna, chose the first three places. The principal recommendations and demands of the district residents were published by the Municipal District Office. Shortly after the closedown of the factory, a syndicate composed of eight developers bought the site. Nevertheless, the course of the future development was already formulated and the developers had to conform to that. This was followed by the one-tier urban design competition, where two winners formed joint venture for the urban master concept and draft.

2. The collaboration and interaction of the stakeholders was an intention from the very beginning of the process. The project management was led by two groups. In the beginning the main significance was devoted to a working group, composed of the planning experts, from a variety of fields and municipal departments, the winners of the urban design competition, and the representatives of the developers. This group served as an instrument of planning information, discussion, and control. Later, the focus shifted to the urban monitoring group which acted as advisory board on the findings and proposals made by the working group. This group relayed on the opinion of primary external experts, but also the representatives of both Chief Executive Office and Municipal Department, as well as the municipal district members. This control group turned to be crucial for the success of the entire process.

3. Negotiation process was on the very high level during the entire project due its organisation. In the beginning phase, intensive information and citizen involvement made the land use plan and the development plan procedures to run very smoothly. Nevertheless, the citizens' advisory board did not participate in the master concept and master project development. This was reserved for the planning experts who still respected the mutual consultation activities. Later, the members of the working group were convinced that the high-quality project can be achieved only through the collateral agreements and area management based on the planning 
work. The mediation phase was achieved in the urban monitoring group through the test projects prepared by the architects and then examined by the developers.

4.In such a complex network composed of several expert groups combined with a great impact of citizens and interwoven with developers' demands, it was not possible to collaborate without conflicts. Some of them were so strong that it seemed the whole process was going to fail. It was particularly expressed within the working group, composed of the members with a different interest background. Nevertheless, the elimination of mutual confrontations was achieved through the sessions of the urban monitoring group. The possible conflicts with the city administration were avoided since the political representatives were the significant part of the urban monitoring group. Before the final draft adoption, it was presented to the citizens' representatives, which ensured the final solution appropriate for all the direct participants in the planning process.

\section{CONCLUDING REMARKS}

From the previous overview of the planning process in the case of the brownfield regeneration we can draw some general characteristics of the collaborative procedures applied in such a process. It is interesting to observe whether the inclusion of certain sectors is prescribed by the legal measures or it represents a personal approach of the interviewees. Thus, from this we can discover the extent to which innovative approaches are implemented in brownfield regeneration process.

When it comes to the Swiss brownfield case, it is the typical example of the so-called test-planning. During test planning procedure, a few basic rules have to be followed. Namely, there is a need for:

- A specific role differentiation (technical evaluation committee, 3-5 design teams, the executive board, and organisation office);

- Three consultation meetings;

- At least three competing teams;

- The simultaneous development of the final draft - there are no winners.

Those rules are the part of an informal planning procedure. They are not regulated by the law, but they surely contribute to an efficient and mean- ingful planning process. The described procedure provides the opportunity to "be smarter when working together". Only jointly recognized problems motivate collaboration. Planner, as an expert, does not insist on his own opinion. On the contrary, the consensus building is the main prerequisite for the successful results of the testplanning procedure.

In the case of the Austrian brownfield regeneration project, the organisational structure of project management can be also drawn:

- A specific organisational roles are divided between working group and urban monitoring group;

- Only one-tier competition, over 20 consultations within the working group, 4 consultations within the urban monitoring group;

- 27 project teams;

- Two prize winners - joint venture urban design.

The working group networked all the relevant stakeholders with no require for formal or legal competence to do so. Also, the one-tier competition is not often seen in the urban design procedures. Nevertheless, this affected all the stakeholders to express their own opinions as much as possible. "Open" planning process resulted in a high-level of mutual understanding. Namely, only three negative opinions were submitted during the draft formulation phase. The final solution was consensus-based, i.e. it was the result of the extensive discussions, well-documented interim planning phases, clearly formulated qualities of the urban design, and avoiding the requirements carrying the risk for implementation.

In the end, there are some general recommendations which were observed within the both cases. Firstly, the role of every expert involved into the planning process has to be differentiated. This means that the professionals in the field of real estate economics, transport, landscape planning, urban planning, etc. have to incorporate their own knowledge, skills and experiences in the concrete process. Expert opinion should be expressed in the early stage of process. It should be provide in the form of explicit answer, e.g. a written progress reports. Also, a careful selection of proven experts should be taken into account.

Also, public relations (PR) are very important and should be approached carefully. Firstly, some common opportunities and problems with a po 
tential to motivate collaboration should be recognized. Later, the document in paper form should be presented in the public exhibition in order to involve a great number of general public.

Finally, to cope with difficult unsolved problems in planning a comprehensive training is required. Besides knowledge and skills in project management, it is important that there is a basic understanding of spatial processes and some experience in the field of designing.

Some of the mentioned general recommendations can be applied within the further projects of brownfield regeneration in Europe and beyond.

\section{REFERENCES}

1) Alker, S., Joy, V., Roberts, J., and Smith, P., (2000) The definition of brownfield, Journal of Environmental Planning and Management, 43(1), 49-69.

2) CABERNET (Concerted Action on Brownfield and Economic Regeneration Network), (2009) Sustainable Brownfield Regeneration, http://www.cabernet.org.uk, preuzeto 10.12.2010.

3) Dixon, T. and Doak, J., (2005) Actors and Drivers: Who and what makes the brownfield regeneration process go round? In: Proc., SUBR:IM conference, Sheffield, UK, http:// www.subrim.org.uk/publications/subrim1stconference/1030_1100actorspaper.doc, preuzeto 25.11.2008.

4) Dixon, T., Raco, M., Catney, P. and Lerner, D. (Eds.), (2008) Sustainable Brownfield Regeneration: Liveable Places from Problem Spaces, Chichester: Wiley.

5) Doak, J. and Karadimitriou, N., (2007) (Re)development, complexity and networks: a framework for research, Urban Studies, 44(2), 1-22.

6) Ferber, U. and Grimski, D., (2002) Brownfields and redevelopment of urban areas, $\mathrm{Vi}$ enna: Austrian Federal Environment Agency on behalf of CLARINET.

7) Grams, A., (2011) [Personal communication], 4 September.

8) Mrđenović, T. (2011): Integrative urban design in regeneration - principles for achieving sustainable places, Journal of Applied Engineering Science, Vol. 9, No. 2, pp. 305-316.
9) Muggli, R., (2008) Spatial planning in Switzerland: a short introduction. In: J. Ryser and T. Franchini (Eds.), International Manual of Planning Practice (IMPP), International Society of City and Regional Planners (ISoCaRP), 304-314.

10) Pamer, V.K., (2011) [Personal communication], 6 November.

11) Prokop, G., Jobstmann, H. and Schönbauer, A., (2011) Report on best practices for limiting soil sealing and mitigating its effects, Luxembourg: European Commission.

12) RESCUE (Regeneration of European Sites in Cities and Urban Environments) (2004III), (2004) Guidance report for the management of the Brownfield Regeneration Projects (Work Package 6, Deliverable 6.1), http://www.rescue-europe.com, preuzeto 13.12.2010.

13) Scholl, B. (Ed.), (2008) Spatial planning and development in Switzerland - observations and suggestions from the international group of experts, Zurich: ETH Zurich, Institute for Spatial and Landscape Development.

14) Schremmer, C., (2010) Austrian Spatial Development Strategy in a European Perspective. In: Proc., Symposium 'Spatial Planning in the Danube Region: A Comparison of Serbia and Austria', Vienna, Austria.

15) Stanilov, K. (Ed.), (2007) The Post-Socialist City: Urban Form and Space Transformations in Central and Eastern Europe after Socialism, Dordrecht: Springer.

16) Staub, B., (2011) [Personal communication], 3 December.

17) Swiss Federal Council, (2008) Sustainable Development Strategy: Guidelines and Action Plan 2008-2011, Bern: Swiss Federal Council.

Paper sent to revision: 26.09.2012.

Paper ready for publication: 01.03.2013. 